Article

\title{
Students in Climate Action: A Study of Some Influential Factors and Implications of Knowledge Gaps in Africa
}

\author{
Mark M. Akrofi ${ }^{1, * \mathbb{D}}$, Sarpong H. Antwi ${ }^{1}{ }^{10}$ and Jabulani R. Gumbo ${ }^{2}$ \\ 1 Institute of Water and Energy Sciences (Incl. Climate Change), Pan African University, Tlemcen 13000, \\ Algeria; antwisarpong1@gmail.com \\ 2 Department of Hydrology and Water Resources, University of Venda, Limpopo 0950, South Africa; \\ jabulani_gumbo@yahoo.co.uk \\ * Correspondence: macakrofi@gmail.com; Tel.: +21-354-291-7127
}

Received: 28 December 2018; Accepted: 25 January 2019; Published: 28 January 2019

\begin{abstract}
This study examined how the regional manifestations of climate change effects and students' involvement in various climate-related clubs and activities influenced their knowledge and awareness of climate change. Key knowledge gaps and their implications for climate action were also examined. A cross-sectional survey was adopted for the study whilst a snowball sampling technique was used to select the respondents. A total of 300 students from 26 African countries participated in the survey. Descriptive statistics, relative importance index (RII) method and the chi-square test of independence were used to analyze the data. Results showed that regional manifestations of climate change effects and students' involvement in climate change-related workshops and campaigns significantly influenced their knowledge levels whilst their membership of climate-related student clubs had no significant influence. Key knowledge gaps with regards to how factors such as meat consumption and waste generation could lead to climate change were also identified. Students were also less knowledgeable about how climate change affects key issues such as conflicts, gender inequalities and job insecurity. Intensification of climate change education beyond the most common causes and effects is highly recommended among the youth. Various environment-related student clubs are also encouraged to tailor their activities in this direction.
\end{abstract}

Keywords: climate change; student clubs; knowledge gaps; youth; climate action

\section{Introduction}

Africa as a continent is highly vulnerable to the threats of climate change because it depends heavily on climate-sensitive economic processes such as agriculture and has limited resources to respond to these threats socially, financially and technologically [1]. Despite the sharp changing weather patterns, most people in Africa, are particularly misinformed about global climate change [2]. Awareness levels are extremely low in Africa with the proportion of people who have never heard about climate change reaching two-thirds of the adult populations in South Africa and Nigeria [3]. This is attributed to limited awareness campaigns on one hand and many other problems such as poverty and political instability in the continent, hence making climate awareness a lesser priority [1]. However, addressing environmental issues such as climate change requires good knowledge and awareness of these issues [4,5]. Watkins [5], for instance, argued that public perception can significantly influence future development and environmental policies. In this regard, public perceptions, awareness and knowledge of climate change have received increased attention in the literature in recent times [6-15]. It is argued that individual behaviour is central to climate change because individuals influence large 
procedures of change and policy decisions [16]. Researching on climate awareness has, therefore, become necessary since climate change threatens social cohesion and development through the occurrence of natural hazards such as fire, flood and drought among others. In doing so, it is essential to involve the youth. Awareness of the youth in the context of climate change is viewed as a means of strengthening the resilience of communities, individuals and systems to climate change and climate variability. Such awareness is necessary to stimulate climate action among students [17-19]. In line with this, world-leading organizations such as the United Nations have stressed the need for youth environmental education. The United Nations Conference on Environment and Development's (UNCED) agenda 21, for instance, states that:

For advancing the role of youth and actively involving them in the protection of the environment ... governments, according to their strategies, should take a measure to ensure access to education for all youth ... which incorporates the concepts of environmental awareness and sustainable development throughout the curricula. [20] (p. 25)

Increasing peoples' awareness through education is an essential measure to drive active participation at all levels of the community in tackling climate change [8]. Agboola and Emmanuel [21], justify the need for awareness and enlightenment on climate change and sustainable development noting that awareness on climate change among the general public is pertinent whilst education is an essential component and catalyst for responding to global climate change. They examined climate change awareness among undergraduate students. Pandve and Raut [22], examined climate change knowledge among medical students, Rahman et al. [23] studied climate change awareness among high school students, Parant et al. [24] inquired into how to raise students' awareness on climate change, and Frejie [25] assessed global warming awareness among university of Bahrain science students. Ayanlade and Jegede [26] studied climate change education and knowledge among university graduates in Nigeria whilst Buggy and McGlynn [27] studied climate change awareness among Tanzania's second-level education system. Whilst these studies present insights about students' knowledge of climate change, key issues such as involving knowledge on indirect causes (such as meat consumption) and effects (such as conflicts and gender inequalities) of climate change were not explored. Also, students participation in climate change workshops and their membership of environment-related student clubs influence their knowledge of climate change needs further inquiry [7]. Improving students' knowledge of climate change can help to raise awareness of the phenomenon in society as a whole [27]. Consequently, Buggy and McGlynn [27] argued that raising climate awareness in society should target the educational system noting that determining students' conceptions and misunderstandings of climate change are paramount. This study thus advances further the course on climate change knowledge among university students in Africa by specifically examining how the regional manifestations of climate change effects, students' involvement in climate-related clubs, and their participation in climate change workshops influence their knowledge and awareness of climate and their self-confidence to educate others about the phenomenon. The study also examines students' knowledge of how factors such as meat consumption and waste generation and management could contribute to global warming and climate change.

\subsection{Climate Change Awareness in Africa}

Africa has the lowest level of awareness of climate change [3]. African countries constituted 9 out of the bottom 10 in 119 countries studied (see Table 1). The proportion of people aware of climate change in these countries ranged between $20.6 \%$ for Liberia and 30.1\% for Morocco. 
Table 1. Top 10 and bottom 10 countries of climate change awareness.

\begin{tabular}{cccccc}
\hline Rank of 119 & Country & Awareness (\%) & Rank of 119 & Country & Awareness (\%) \\
\hline 1 & Japan & 98.9 & 110 & Morocco & 30.1 \\
2 & United States & 97.7 & 111 & Togo & 29.6 \\
3 & Finland & 97.6 & 112 & Nigeria & 27.8 \\
4 & Norway & 97.5 & 113 & Zambia & 26.5 \\
5 & United Kingdom & 97.4 & 114 & Ghana & 26.4 \\
6 & Australia & 97.3 & 115 & Afghanistan & 25.4 \\
7 & Sweden & 96.1 & 116 & Egypt & 25.0 \\
8 & Germany & 96.0 & 117 & Burundi & 21.7 \\
9 & Netherlands & 95.6 & 118 & Benin & 20.7 \\
10 & Canada & 95.4 & 119 & Liberia & 20.6 \\
\hline
\end{tabular}

Source: [3].

Contrary to the findings in Table 1, several studies have indicated high levels of climate change awareness in Africa [10,28,29]. As a possible reason for this contrast, Lee et al. [3] focused on the general public in the countries studied, whilst the other studies indicating high levels of awareness were carried out with specific groups such as farmers, students or stakeholders whose activities are directly related to climate change. However, despite a high level of awareness of changing weather patterns, most people are not well-informed about climate change [2]. A study by Aphunu and Nwabeze [28] found out that, farmers' knowledge about the impacts of climate change was low although they were aware of climate change. Similarly, albeit a high level of awareness, $60 \%$ of farmers in the Niger Delta knew little or nothing about the impacts of climate change [10]. In another study of farmers' perception of climate change and responsive strategies, the majority (94.67\%) of the farmers were aware of climate change however, there was a lack of awareness of climate change related insurance products which the farmers could utilize to strengthen their resilience strategies [29].

\subsection{Climate Action Defined}

Climate action purports to strengthen resilience and adaptive capacity to climate-induced hazards and natural disasters [30]. UNDP [31] adds that climate action means improving education, awareness creation, institutional capacities and making climate change measures an integral part of national policies in order to abate greenhouse gas emissions and strengthen resilience towards climate-stimulated impacts. According to the European Commission [32] (p. 2):

"Climate action is understood to include mitigating climate change (i.e., contribution to the reduction of greenhouse gas emissions), adapting to the impacts of climate change by building resilience (e.g., regarding floods, droughts, extreme weather events etc.), and understanding the underlying causes of climate change."

Activities that constitute climate action are varied and range from technological innovation such as carbon capture and storage to lifestyle activities such as cycling, walking and using public transport [32]. This implies that whether individuals or organizations, everyone has an important role in climate action. As Werft [33] puts it; “ . . it basically means doing your part to keep the planet clean and healthy" (p. 1). Inferring from the above perspectives, we define climate action in the context of this study as any activities undertaken by individuals, organizations or governments which are geared towards reducing global warming, adapting to and mitigating climate change impacts in order to ensure a healthy and sustainable environment.

\subsection{Theoretical Framework}

Patchen [13] argued that the importance of individuals' knowledge and attitude should be central to improving natural environments. This is because people's perception of the environment and their concern for environmental problems can be seen in their attitudes [34]. It is, therefore, argued that 
people with positive attitudes can play a significant role in environmental preservation [35]. Ajzen [36] postulates that attitudes translate into intentions and intentions translate into behaviour. Consequently, in his theory of a planned behaviour model, Ajzen [36] places significant emphasis on assessing attitudes. Upon encountering new information or situations, individuals' initial attitudes might be challenged or changed, hence a change in attitude is based on new information or situations [37]. An individual's intention to portray a particular behaviour is the central tenet of the theory of planned behaviour. This intention indicates the extent of zeal and effort that a person will make to perform a behaviour and is determined by the attitude towards the behaviour, subjective norms and supposed behavioural control [36]. Relating this theoretical viewpoint to climate action, it is argued that interventions dealing with behaviour such as environmental awareness campaigns aim to create new attitudes and perceptions about a new behaviour by changing mediating factors such as knowledge and social norms [36,37]. Similarly, social cognitive theory [38,39] postulates that human behaviour interacts in 'triadic reciprocality' where human factors and environmental influences are all interactive determinants of each other. Central to this theory is the concept of self-efficacy which involves peoples' self-confidence about their capacity to perform certain tasks or undertake a particular behaviour [40]. According to Bandura [41,42], individuals' confidence about their self-efficacy influences their choice of activities and behaviours and also their perseverance in such activities especially in difficult situations. In their proposed model for understanding awareness, knowledge and perception of climate change in Malaysia, Mashud et al. [34] postulated that awareness, knowledge and perception of climate change influence attitudes towards climate change and, consequently, pro-environmental behaviour.

Inferring from these theoretical perspectives, it can be deduced that the impetus to take climate action can be seen in peoples' attitude and behaviour towards environmental issues. These attitudes and behaviours are, however, dependent on their level of awareness and knowledge about climate change issues. Hence, peoples' experience of the effects of climate change, their participation in climate change workshops and campaigns, membership of environmentalist groups, access to climate information among others will influence their momentum to take climate action. This is because such factors will significantly increase their awareness and knowledge of these issues. This will trigger the inner impulse to take action which will consequently reflect in their attitudes and behaviour. In this study, we examine how students' participation in climate change workshops and campaigns, their membership of climate and environment-related student clubs, and regional manifestation of climate change effects influence their knowledge of climate change and their self-confidence about educating other people on climate change.

\section{Materials and Methods}

\subsection{Study Design and Selection of Respondents}

The study employed a cross-sectional survey [43] to gather responses from university students located in various countries across Africa. Smith's [44] formula for determining sample size was employed. Using a confidence level of $95 \%$, standard deviation of 0.5 , a $5 \%$ margin of error and a corresponding Z-score of 1.96, we employed the formula: Necessary Sample Size = $(Z \text {-score })^{2 *} \operatorname{StdDev}^{*}(1-\mathrm{StdDev}) /(\text { margin of error })^{2}$ [44]. The resultant sample size is 384 . Snowball sampling technique was used in selecting respondents for the study. This method was used in order to ensure that we gathered data from university students only and from different countries in Africa. In doing so, an initial group of 40 students from 28 different African countries were selected at the Pan African University Institute of Water and Energy Sciences (PAUWES) which is located in the University of Tlemcen in Algeria. Each student was then tasked to identify and share through email (with the guidance of the researchers) the questionnaire with at least 10 other university students that they know back in their countries. In all, 300 responses were received giving a non-response of 84 . However, according to Israel [45], a sample size ranging between 200 and 500 is often good enough 
for statistical analyses. Hence, the non-response of 84 is expected to have no significant effect on the findings of the study.

\subsection{Data Collection and Analysis}

A structured questionnaire was administered through the internet using Google forms. The questionnaire entailed close-ended questions which were drafted based on a review of questionnaires used by similar studies $[6,7,9,46,47]$. The link to the online questionnaire was administered through emails using a process similar to Salant and Dillman's [48] four-stage process for administering questionnaires by mail or post. The use of emails was convenient for the study because the participants are widely dispersed and since they are university students, it is easy for the questionnaire to be self-administered. The questionnaire was well-structured with detailed instructions and the questions were concise, simple and easy to answer. After gathering the email addresses of as many students as possible from the initial 40 students from their respective countries, a first email was sent with a short notice letter informing them about the survey. A week after the advance notice letter, a second email containing the link to the online questionnaire was sent to the students. Finally, when the responses to the survey came to a standstill (after about three weeks), we sent another email to all students who participated in the survey thanking them for taking time to fill out the questionnaire. For ethical purposes, a consent statement was written on the first section of the questionnaire and respondents were assured of the confidentiality of their responses. Also, no personal information such as names was requested. The questionnaire was pre-tested to ensure validity and reliability before it was deployed. This was done with students at the PAUWES and the University of Tlemcen in Algeria.

Results were analyzed using Microsoft Excel and the statistical package for the social sciences (SPSS) version 23. Student's knowledge of the causes and effects of climate change and global warming were analyzed using the relative importance index (RII) method $[49,50]$. Based on the review of questionnaires used by related studies, specific statements about global warming and climate change with regards to the causes, effects and mitigation of climate change were included in our questionnaire and respondents were asked to indicate the extent to which they agreed or disagreed with these statements on a Likert scale of 1 to 5 . Individual frequencies of each statement were multiplied by its corresponding rating (that is, $1,2 \ldots 5$ ) which was then summed up. This sum was divided by the product of the total number of respondents $(N)$ and the highest point on the Likert scale (5). The formula for this calculation is given as: $R I I=\frac{\sum W}{A * N}$ [51] where $W$ is the rating given to each statement by the respondents and ranges from 1 to $5, A$ is the highest point on the Likert scale (5), and $N$ is the total number of respondents. The chi-square test of independence within the SPSS package was also used to ascertain the relationships between students' participation in climate change-related workshops and clubs, and their level of knowledge on climate change.

\section{Results and Discussions}

\subsection{Background of Respondents}

A total of 300 students participated in the survey. Of this number, males and undergraduate students constituted the majority with proportions of $63.0 \%$ and $56.0 \%$ respectively. Figure 1 shows the distribution of responses from various countries. 


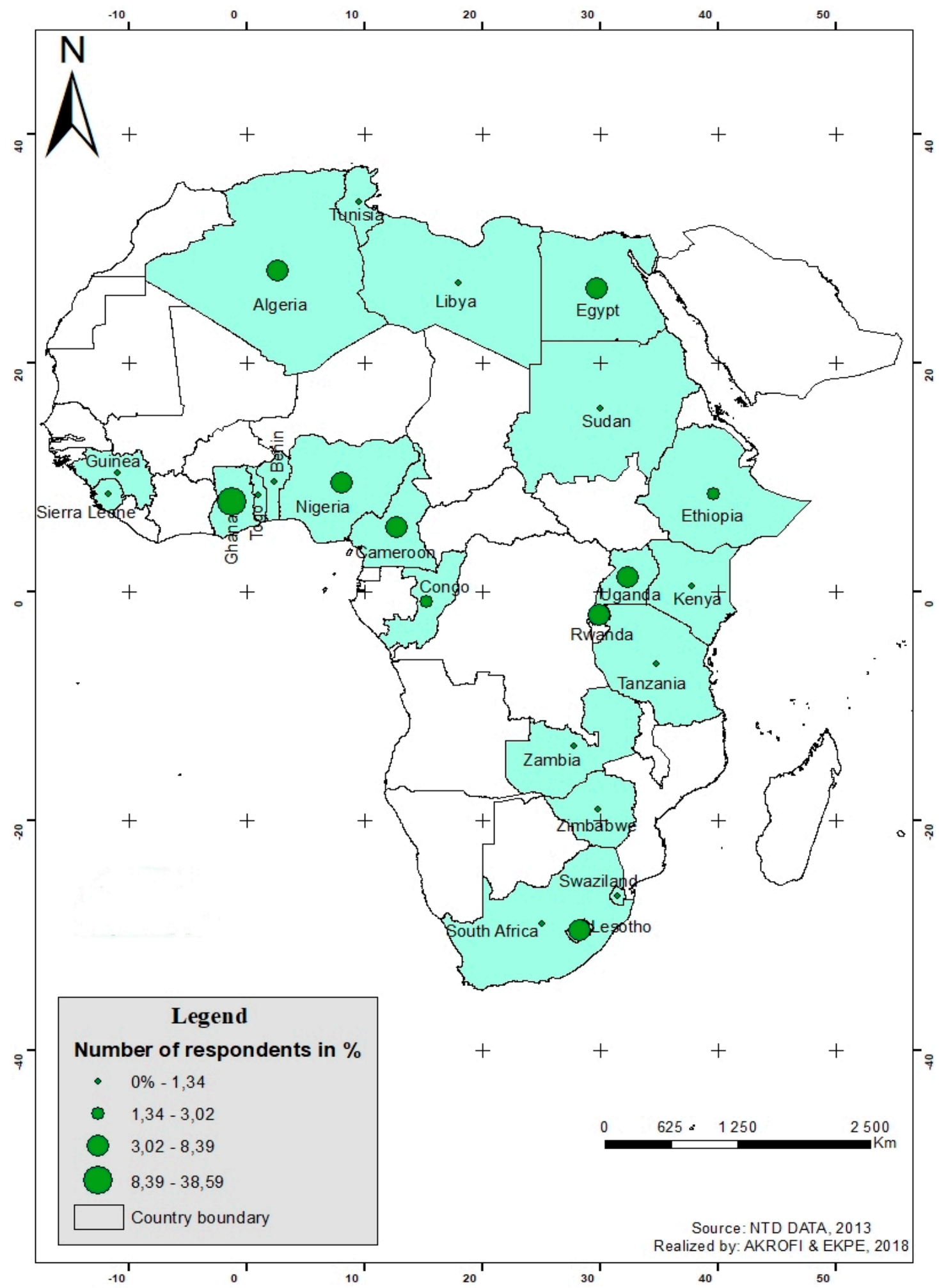

Figure 1. Map showing the percentage of respondents from each country.

The largest proportion of students (20.7\%) were studying in the field of policy/planning/ development studies whilst a significant proportion (17.0\%) were studying in the field of engineering/technological sciences. The least studied fields were visual and performing arts $(0.3 \%)$ and communication/journalism studies ( $0.3 \%)$. Figure 2 presents responses by fields of study. 


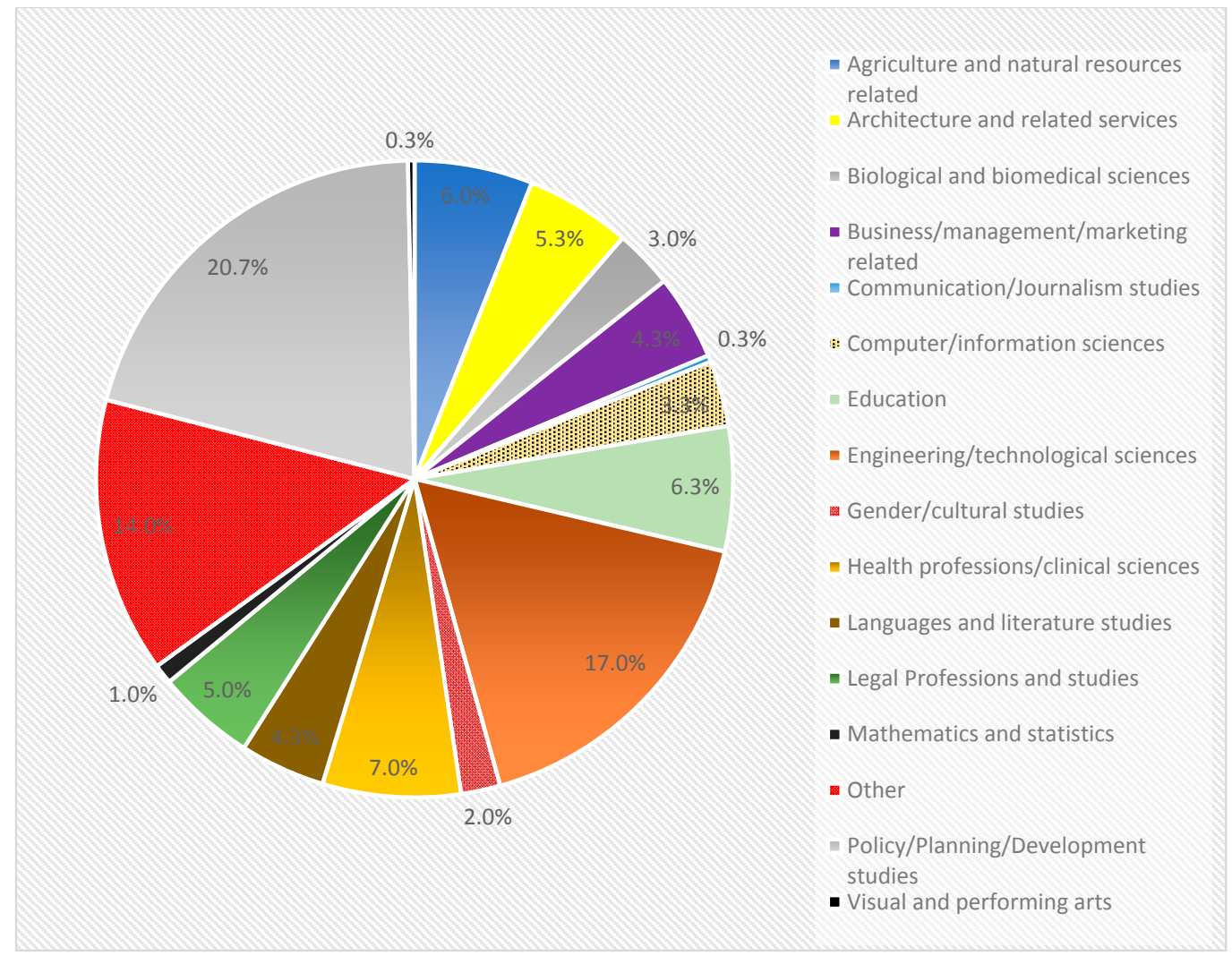

Figure 2. Fields of study of the respondents (Authors' survey data, 2018).

\subsection{Students' Knowledge of the Causes of Climate Change}

Almost all students (99.0\%) who participated in the survey agreed that global climate is changing. The level of students' knowledge of climate change and global warming was assessed with respect to the causes, effects and mitigation of climate change impacts. Table 2 presents the results of students' ratings for the causes of climate change.

Table 2. Student's ratings of the causes of climate change.

\begin{tabular}{|c|c|c|c|c|c|c|c|c|}
\hline \multirow{2}{*}{ Factor } & \multicolumn{5}{|c|}{ Ratings (W) } & \multirow{2}{*}{$\sum W^{*} N$} & \multirow{2}{*}{ RII } & \multirow{2}{*}{ RANK } \\
\hline & 1 & 2 & 3 & 4 & 5 & & & \\
\hline Cutting down trees cause climate change & 0 & 2 & 9 & 75 & 214 & 1401 & 0.934 & 1 st \\
\hline Using fossil fuels cause climate change & 0 & 7 & 17 & 114 & 162 & 1331 & 0.887 & 2nd \\
\hline Industrialization causes climate change & 4 & 6 & 18 & 105 & 167 & 1325 & 0.883 & $3 \mathrm{rd}$ \\
\hline $\begin{array}{c}\text { More garbage/improper waste disposal causes } \\
\text { climate change }\end{array}$ & 2 & 8 & 39 & 97 & 154 & 1293 & 0.862 & 4 th \\
\hline $\begin{array}{l}\text { Increase in number of automobiles cause } \\
\text { climate change }\end{array}$ & 8 & 11 & 21 & 117 & 143 & 1276 & 0.851 & 5 th \\
\hline $\begin{array}{l}\text { Using firewood and charcoal for cooking causes } \\
\text { climate change }\end{array}$ & 9 & 22 & 40 & 120 & 109 & 1198 & 0.799 & 6th \\
\hline $\begin{array}{l}\text { Climate change is just a natural fluctuation in } \\
\text { earth's temperatures }\end{array}$ & 36 & 96 & 40 & 81 & 47 & 907 & 0.605 & 7 th \\
\hline Eating too much meat causes climate change & 138 & 67 & 48 & 36 & 11 & 615 & 0.41 & 8 th \\
\hline Climate change is a punishment from lesser gods & 167 & 55 & 45 & 19 & 14 & 558 & 0.372 & 9th \\
\hline
\end{tabular}


With regard to causes, students ranked cutting of trees (deforestation) as the most important cause of climate change and global warming. The use of fossil fuels and rapid industrialization were ranked second and third respectively as the most important causes of climate change. The rankings of these three factors point to the fact that climate change and global warming are mostly caused by human activities as found by similar studies [7,52]. The rankings of factors such as 'improper waste disposal' (4th), 'eating too much meat' (8th) and 'increase in the number of automobiles' (5th) however, have implications for individual level and attitudinal measures that can help to reduce climate change and global warming. These factors significantly contribute to global warming and students are most likely to engage in them (especially eating of meat and waste generation) on a daily basis than the first three factors (deforestation, use of fossil fuels and industrialization) that they ranked as the most important.

According to Gerber et al. [53], total greenhouse gas emissions are approximately 7.1 gigatonnes $\mathrm{CO}_{2}$-eq (representing $14.5 \%$ of anthropogenic emissions) from the supply chain of livestock every year. Cattle contribute the largest emissions (65\%) with pigs, buffalo, chicken and small ruminants contributing significant amounts of emissions as well. Also, 2.1 million hectares of deforestation have been linked to cattle production [54]. Cutting down the consumption of beef could thus, significantly help to stop harming the planet through greenhouse gas emissions [55]. Plastics are used on a daily basis ranging from water bottles to shopping bags resulting in some 300 million metric tonnes of plastics being produced globally each year [56]. The ranking of these factors by the students suggests that they do not have much knowledge about these facts and hence they might be contributing more to the problem of global warming than they thought. This perhaps explains why out of seven statements, they ranked 'nothing I do on a daily basis contributes to the problem of climate change' as fifth (see Table 3). Knowing the causes of climate change is a major determinant of both the intent to take voluntary actions and to influence government policies with regards to climate change [57].

\subsection{Students' Knowledge of the Effects of Climate Change}

Analysis of results on the effects of climate change shows that, apart from the most commonly known effects of climate change such as droughts and heat waves, low crop yields and water shortages, respondents did not have much knowledge about how climate change affects other sectors especially the social sector because they ranked climate change effects in this sector as less important. Out of 11 statements about the effects of climate change, respondents ranked 'climate change causes gender and income inequalities', 'climate change causes conflicts and wars' and 'climate change leads to job insecurity' as the least important with ranks of 11th, 10th and 9th respectively (see Table 3). Recent studies have increasingly shown that climate change is a major driver of social inequalities [58,59], conflicts and wars [60-62] and job insecurity [63]. The rankings, however, show that many students do not know much about these linkages. When asked whether they believe climate change will affect their career or not, $37 \%$ of respondents were uncertain (their response was 'maybe') while $8 \%$ of them believed that climate change will not affect their career in any way.

Table 3. Student's ratings of the effects of climate change.

\begin{tabular}{|c|c|c|c|c|c|c|c|c|}
\hline \multirow{2}{*}{ Factor } & \multicolumn{5}{|c|}{ Ratings (W) } & \multirow{2}{*}{$\sum W^{*} N$} & \multirow{2}{*}{ RII } & \multirow{2}{*}{ Rank } \\
\hline & 1 & 2 & 3 & 4 & 5 & & & \\
\hline Climate change causes droughts and heat waves & 1 & 4 & 16 & 102 & 177 & 1350 & 0.9 & $1 \mathrm{st}$ \\
\hline $\begin{array}{c}\text { Climate change causes low crop yields and leads } \\
\text { to food insecurity }\end{array}$ & 4 & 0 & 24 & 98 & 174 & 1338 & 0.892 & 2nd \\
\hline $\begin{array}{l}\text { Climate change affects water supply and } \\
\text { water quality }\end{array}$ & 2 & 12 & 18 & 113 & 155 & 1307 & 0.871 & $3 \mathrm{rd}$ \\
\hline $\begin{array}{c}\text { Climate change causes a rise in sea level and } \\
\text { ocean acidity }\end{array}$ & 2 & 7 & 38 & 98 & 155 & 1297 & 0.865 & 4th \\
\hline
\end{tabular}


Table 3. Cont.

\begin{tabular}{|c|c|c|c|c|c|c|c|c|}
\hline \multirow{2}{*}{ Factor } & \multicolumn{5}{|c|}{ Ratings (W) } & \multirow{2}{*}{$\sum W^{*} N$} & \multirow{2}{*}{ RII } & \multirow{2}{*}{ Rank } \\
\hline & 1 & 2 & 3 & 4 & 5 & & & \\
\hline Climate change causes biodiversity loss & 3 & 5 & 36 & 110 & 146 & 1291 & 0.861 & 5 th \\
\hline Climate change causes flooding & 4 & 14 & 44 & 96 & 142 & 1258 & 0.839 & 6th \\
\hline $\begin{array}{l}\text { Climate change increases the risk of illness and } \\
\text { death from extreme heat and poor air quality }\end{array}$ & 3 & 14 & 29 & 134 & 120 & 1254 & 0.836 & 7th \\
\hline Climate change affects renewable energy sources & 1 & 20 & 44 & 130 & 105 & 1218 & 0.812 & 8 th \\
\hline Climate change leads to job insecurity & 22 & 44 & 74 & 107 & 53 & 1025 & 0.683 & 9th \\
\hline Climate change cause conflicts and wars & 44 & 54 & 88 & 77 & 37 & 909 & 0.606 & 10th \\
\hline $\begin{array}{l}\text { Climate change cause gender and } \\
\text { income inequalities }\end{array}$ & 55 & 40 & 109 & 72 & 24 & 870 & 0.58 & 11th \\
\hline
\end{tabular}

Source: authors' survey data (2018).

The survey results indicate that respondents' knowledge of climate change and global warming was influenced by the regional manifestation of climate change effects. For instance, the recent transboundary water conflict in Central and Eastern Africa involving the Congo basin and Nile river, respectively, have been linked to climate change. This conflict is one of the prominent and widely discussed issues with regard to water conflict in Africa and, hence, it is not surprising that many students in the affected regions agreed to the statement 'climate change cause conflicts and wars' than students outside of these regions (see Figure 3). From Figure 3, overall agreement (both 'strongly agree' and 'agree') to this statement is highest among students in East Africa (57.7\%) and North Africa $(45.8 \%)$ whilst it is lowest in West Africa $(26.4 \%)$.

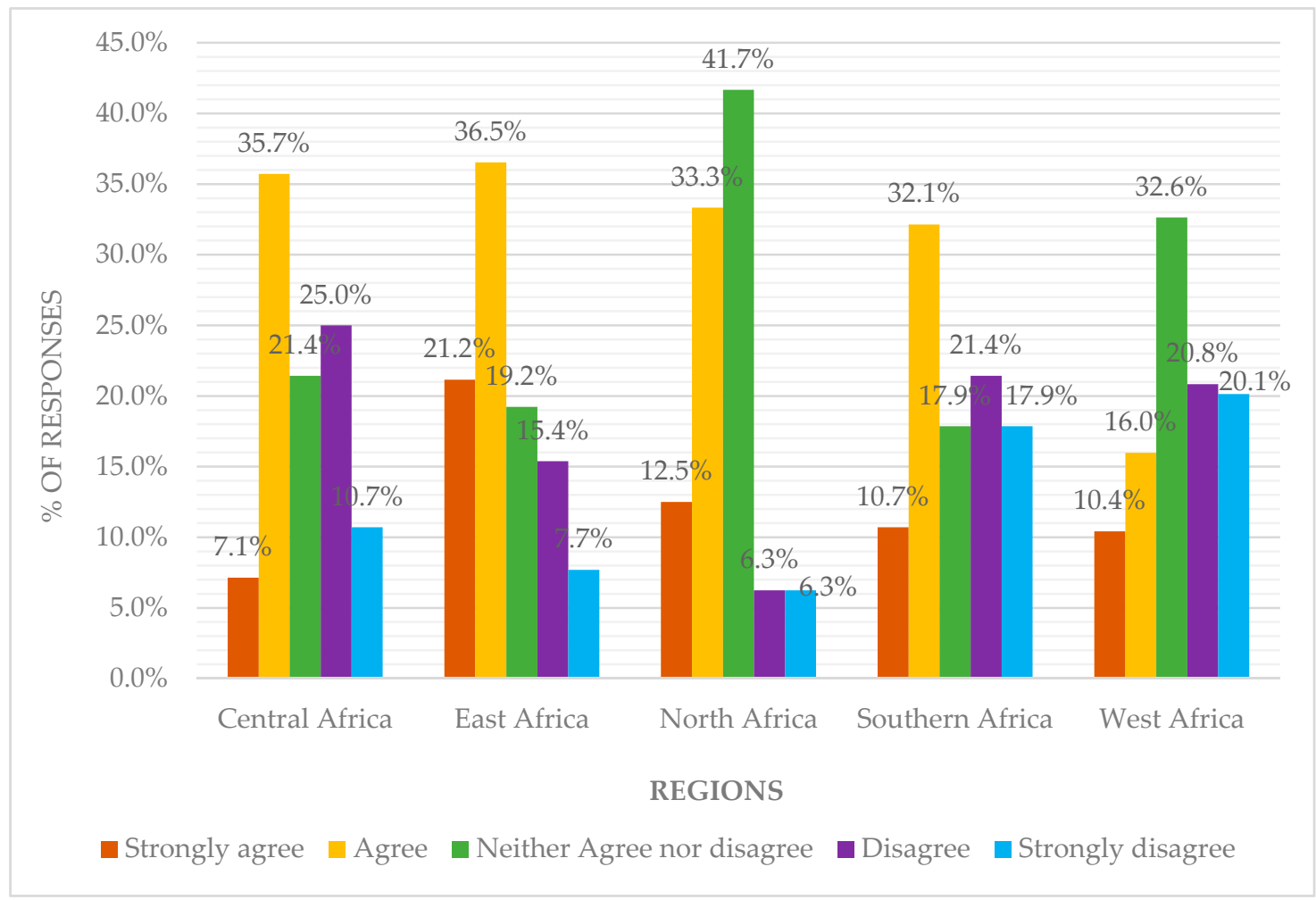

Figure 3. Students' knowledge of climate change effects on conflict and wars by region (authors' survey data, 2018). 
Droughts and water shortages are major manifestations of climate change effects in Africa especially in the Eastern [64], Southern (for example the recent water crisis in Cape town) and Northern Africa [65]. Consequently, students in these regions attested to water shortages as the result of climate change. From Figure 4, the majority of students in East Africa (71.2\%), South Africa (67.9\%) and North Africa (52.1\%) 'agree' to the statement; 'climate change affects water supply and water quality' whilst 53.6\% of students in Central Africa 'strongly agreed'. This finding is in support of the position that an individual's knowledge and awareness of climate change is influenced by the manifestations of the climate change impacts in their localities. Authors such as Lorenzoni and Pidgeon [12], and Lowe et al. [14] noted that peoples' perception of climate change is tied to their direct experiences. Similarly, Ojomo et al. [7] argued that drought and desertification were less selected as the effects of climate change by their survey respondents who were located in the southern part of Nigeria because these effects were more likely to be evident in the northern part of the country than the south.

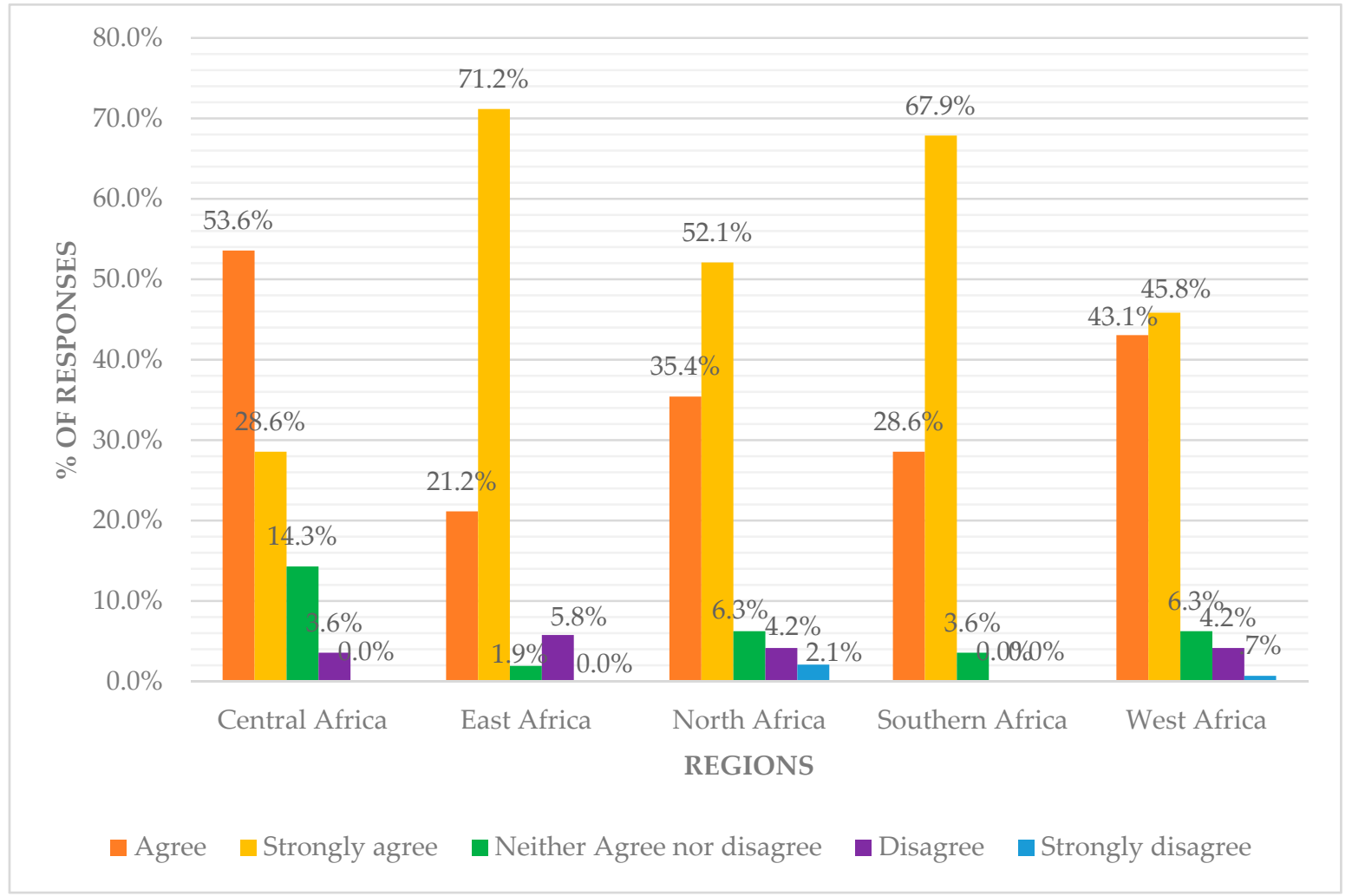

Figure 4. Students' knowledge of climate change effects on water supply and water quality (Authors' survey data, 2018).

\subsection{Students' Perspective on Climate Action}

With regard to climate action, students agreed to the fact that we can all contribute to reduce the effects of climate change. Overall, $94.0 \%$ of the respondents agreed (65.0\% 'strongly agreed' and $29.0 \%$ 'agree') that we can all take action either as individuals or organizations to address climate change. The students also believed that switching from fossil fuels to renewable energy sources can help to address global warming and climate change. Most of them 'strongly agree' (44.0\%) while 37.3\% 'agree' that this option is crucial to tackling climate change. This came out as the second important factor with regard to climate action whilst the statement 'we can all do our bit to reduce climate change' was the most important factor. Students were, however, of the view that, governments are not doing enough to tackle climate change. This came out as the third important factor after the RII analysis (see Table 4). 
Table 4. Student's views on climate action.

\begin{tabular}{|c|c|c|c|c|c|c|c|c|}
\hline \multirow{2}{*}{ Factor } & \multicolumn{5}{|c|}{ Ratings (W) } & \multirow{2}{*}{$\sum W^{*} N$} & \multirow{2}{*}{ RII } & \multirow{2}{*}{ Rank } \\
\hline & 1 & 2 & 3 & 4 & 5 & & & \\
\hline We can all do our bit to reduce the effects of climate change & 1 & 3 & 14 & 87 & 195 & 1372 & 0.915 & 1 st \\
\hline Using renewable energy reduces climate change & 4 & 16 & 36 & 112 & 132 & 1252 & 0.835 & 2nd \\
\hline $\begin{array}{c}\text { The government is not doing enough to tackle } \\
\text { climate change }\end{array}$ & 14 & 34 & 59 & 122 & 71 & 1102 & 0.735 & $3 \mathrm{rd}$ \\
\hline $\begin{array}{c}\text { Climate change is inevitable because of the way modern } \\
\text { society works }\end{array}$ & 23 & 49 & 56 & 117 & 55 & 1032 & 0.688 & 4 th \\
\hline $\begin{array}{l}\text { Nothing I do on a daily basis contributes to the problem of } \\
\text { climate change }\end{array}$ & 71 & 88 & 70 & 54 & 17 & 758 & 0.505 & 5 th \\
\hline $\begin{array}{c}\text { Nothing I do on a daily basis makes any difference to } \\
\text { reducing climate change }\end{array}$ & 88 & 95 & 74 & 30 & 13 & 685 & 0.457 & 6th \\
\hline It is already too late to do anything about climate change & 99 & 101 & 65 & 22 & 13 & 649 & 0.433 & 7th \\
\hline
\end{tabular}

\subsection{Influence of Climate-Related Workshops and Clubs on Students' Knowledge and Awareness of Climate Change}

Based on their findings, Ojomo et al. [7] suggested that for future research, the effects of climate change awareness campaigns and workshops on university students should be examined. In line with this, we examined the relationship between students' participation in such campaigns, their membership in climate change and environment-related student clubs and their awareness of climate change and global warming. This analysis was done using the chi-square test of independence. It emerged that students' participation in climate change workshops or programs significantly influenced $\left(\chi^{2}=9.507, p=0.002\right)$ their level of knowledge on climate change and their confidence about educating others about the phenomenon. All (100\%) students who have participated in such workshops indicated that they can educate others about the causes and effects as well as the mitigation measures of climate change. Students who participated in such workshops are also more conscious of climate change effects on other aspects of society other than the natural and physical environment. Contrary to the general ratings of climate change effects on conflicts and on gender and income inequalities as less important, the chi-square test revealed a strong association between students' participation in workshops and their ratings of climate change effects on conflicts $\left(\chi^{2}=21.241, p=0.000\right)$, gender and income inequalities $\left(\chi^{2}=24.503, p=0.000\right)$. Overall, $54.7 \%$ and $47.2 \%$ of students who participated in workshops agreed (strongly agree/agree) that climate change brings about conflicts and, gender and income inequalities respectively whilst only $28.6 \%$ and $22.4 \%$ of students who have not participated in any of such workshops or programs agreed to this. Students who participated in climate change related workshops also see the possibility of climate change affecting their career (72.2\%) than students who did not participate in such workshops or programs $(45.3 \%)$ with a strong association between the two variables $\left(\chi^{2}=21.421, p=0.000\right)$. The relationship between climate and environment-related student clubs and their knowledge and awareness of climate change was also assessed. No significant relationship was found as all $p$ values from the chi-square test for the above variables were greater than the significance level of 0.005 . Also, the visibility of climate change-related organizations appears to be low as nearly half ( $48 \%$ ) of students were not aware of any such organizations in their localities. This provides an opening for climate-related organizations to expand their engagement and activities across the continent.

\section{Conclusions and Recommendations}

Young people around the world are actively involved in climate action ranging from awareness raising to the implementation of climate change adaptation and mitigation initiatives. Enriching them with the requisite knowledge on climate change is thus vital especially in a place like Africa where they constitute the majority of the population. A key and common place where such knowledge is usually 
imparted is university. As such, this study focused on assessing awareness levels and knowledge gaps among university students in Africa. Findings of the study showed that generally, students were aware of the most common and direct causes (deforestation and use of fossil fuels) and effects (droughts and heat waves, low crop yields and water shortages) of climate change. However, students were not very aware of how factors such as meat consumption, improper waste disposal and use of automobiles which they more likely engage in on daily basis can lead to climate change and how climate change impacts affect issues such as conflicts, gender inequalities and job security. This implies that students might be contributing more to the problem of global warming and climate change than they thought. Also, they will not be able to educate others about how such factors contribute to climate change or how climate change affects essential issues such as conflicts, job security and gender inequalities which are pertinent issues in Africa. Thus, it is paramount that workshops organized for the purpose of climate change education and awareness focus on enlightening students and youth in general on the causal linkages between the little things that they do on a daily basis and climate change. Various climate and environment-related student clubs should also tailor their activities in this direction. Where such clubs are non-existent, their establishment for this purpose and other climate-related activities is encouraged. Climate change-related organizations are also encouraged to increase their public engagement, especially in schools.

\section{Limitations and Recommendations for Future Research}

It must be acknowledged that the number of students who participated in this study is small in proportion to the total number of university students in Africa. Hence, the intent of this study was not to generalize the findings for all students in Africa but rather to offer insights about the dynamics of climate change knowledge and awareness among university students in Africa. The sample size, however, does not affect the substantive responses of the study considering the fact that all students who participated in the survey were university students in different parts of Africa and they were the main targets of the study. Hence, there is no non-response bias. Holbrook, Krosnick and Pfent [66] explain that non-response bias occurs when participants and non-participants or respondents in the survey differ on the variables or dimensions that are of interest to the study. In our case, these dimensions include university students located in the different regions of Africa (West, East, Central, North and South Africa) and we obtained responses from students in all these regions. The approach used in selecting the respondents was to ensure that we obtained reliable responses from the target group. A future study could, however, include a larger sample size and where possible, equal representation from each region or country.

Author Contributions: Conceptualization, M.M.A. and S.H.A.; methodology, M.M.A.; validation, J.R.G. and S.H.A.; writing —original draft preparation, M.M.A.; writing—review and editing, J.R.G. and S.H.A.

Funding: This research received no external funding.

Acknowledgments: The authors would like to thank all students at the Pan African Institute of Water and Energy Sciences (including climate change)-PAUWES, and members of the PAUWES Climate Change and Gender Club who helped in gathering data for this study by distributing the questionnaire used to university students in their respective countries. Our sincere thanks also go to the two anonymous reviewers for their insightful suggestions which helped to improve this paper.

Conflicts of Interest: The authors declare no conflicts of interest.

\section{References}

1. UNFCC. Climate Change: Impacts, Vulnerabilities and Adaptation in Developing Countries. Climate Change Secretariat (UNFCCC). 2007. Available online: https://unfccc.int/resource/docs/publications/impacts.pdf (accessed on 3 September 2018).

2. Godfrey, A.; Le Roux-Rutledge, E.; Cooke, S.; Burton, M. Africa Talks Climate: The Public Understanding of Climate Change in Ten Countries; Department for International Development: London, UK, 2009. Available online: http:/ / downloads.bbc.co.uk/rmhttp/mediaaction/pdf/AfricaTalksClimateExecutiveSummary.pdf (accessed on 14 September 2018). 
3. Lee, T.M.; Markowitz, E.M.; Howe, P.D.; Ko, C.Y.; Leiserowitz, A.A. Predictors of Public Climate Change Awareness and Risk Perception around the World. Nat. Clim. Chang. 2015, 5, 1014. [CrossRef]

4. Stern, N. The Economics of Climate Change Executive Summary. United Kingdom. 2006. Available online: https://www.humphreyfellowship.org/system/files/stern_summary__what_is_the_economics_ of_climate_change.pdf (accessed on 5 September 2018).

5. Watkins, K. Human Development Report 2007/2008: Fighting Climate Change: Human Solidarity in a Dividend World; UNDP: New York, NY, USA, 2007; Available online: http:/ / hdr.undp.org/sites / default/files / reports / 268/hdr_20072008_en_complete.pdf (accessed on 5 September 2018).

6. Hope, S. Knowledge, Attitudes and Practices: Study on Climate Change Adaptation and Mitigation in Guyana; UNDP: New York, NY, USA, 2016; Available online: http://adaptationundp.org/sites/default/files/ resources/climate_change_kap_survey_report_guya_0.pdf (accessed on 11 October 2018).

7. Ojomo, E.; Elliott, M.; Amjad, U.; Bartram, J. Climate Change Preparedness: A Knowledge and Attitudes Study in Southern Nigeria. Environments 2015, 2, 435-448. [CrossRef]

8. Ochieng, M.; Koske, J. The Level of Climate Change Awareness and Perception among Primary School Teachers in Kisumu Municipality, Kenya. Int. J. Humanit. Soc. Sci. 2013, 3, 174-179.

9. Maponya, P.; Mpandeli, S.; Oduniyi, S. Climate Change Awareness in Mpumalanga Province, South Africa. J. Agric. Sci. 2013. [CrossRef]

10. Nzeadibe, T.C.; Egbule, C.L.; Chukwuone, N.A.; Agu, V.C. Climate Change Awareness and Adaptation in the Niger Delta Region of Nigeria. African Technology Policy Studies Network Working Paper Series No. 57. 2011. Available online: https:/ / www.africaportal.org/publications/climate-change-awareness-andadaptation-in-the-niger-delta-region-of-nigeria/ (accessed on 21 September 2018).

11. Sundblad, E.L.; Biel, A.; Gärling, T. Knowledge and Confidence in Knowledge about Climate Change among Experts, Journalists, Politicians, and Laypersons. Environ. Behav. 2009, 41, 281-302. [CrossRef]

12. Lorenzoni, I.; Pidgeon, N.F. Public Views on Climate Change: European and USA Perspectives. Clim. Chang. 2006, 77, 73-95. [CrossRef]

13. Patchen, M. Public Attitudes and Behavior Change: What Shapes Them and How to Influence Them. PCCRC Outreach Publication 0601. 2006. Available online: https:/ /www.columban.jp/upload_files/data/EE0063_ AttitudeChange.pdf (accessed on 15 October 2018).

14. Lowe, T.; Brown, K.; Dessai, S.; De França Doria, M.; Haynes, K.; Vincent, K. Does Tomorrow Ever Come? Disaster Narrative and Public Perceptions of Climate Change. Public Underst. Sci. 2006, 15, 435-457. [CrossRef]

15. Doss, C.R.; Morris, M.L. How Does Gender Affect the Adoption of Agricultural Innovations?: The Case of Improved Maize Technology in Ghana. Agric. Econ. 2000, 25, 27-39. [CrossRef]

16. Liverani, A. Climate Change and Individual Behavior. The World Bank Policy Research Working Paper 5058. 2009. Available online: http:/ / documents.worldbank.org/curated/en/913191468156569145/pdf/WPS5058. pdf (accessed on 13 November 2018).

17. McMillan, E.E.; Wright, T.; Beazley, K. Impact of a University-Level Environmental Studies Class on Students' Values. J. Environ. Educ. 2004, 35, 19-27. [CrossRef]

18. Kuhlemeier, H.; van den Bergh, H.; Lagerweij, N. Environmental Knowledge, Attitudes, and Behavior in Dutch Secondary Education. J. Environ. Educ. 1999, 30, 4-14. [CrossRef]

19. O'Connor, R.E.; Bord, R.J.; Fisher, A. Risk Perceptions, General Environmental Beliefs, and Willingness to Address Climate Change. Risk Anal. 1999, 19, 461-471. [CrossRef]

20. UNCED. AGENDA 21. In United Nations Conference on Environment \& Development; United Nations: Rio de Janerio, Brazil, 1992; Available online: https:/ / sustainabledevelopment.un.org/content/documents / Agenda21.pdf (accessed on 20 November 2018).

21. Agboola, O.S.; Emmanuel, M. Awareness of Climate Change and Sustainable Development among Undergraduates from Two Selected Universities in Oyo State, Nigeria. World J. Educ. 2016, 6, 70. [CrossRef]

22. Pandve, H.; Raut, A. Assessment of Awareness Regarding Climate Change and Its Health Hazards among the Medical Students. Indian J. Occup. Environ. Med. 2011, 15, 42. [CrossRef]

23. Rahman, S.M.A.; Tasmin, S.; Uddin, M.K.; Islam, M.T.; Sujauddin, M. Climate Change Awareness among the High School Students: Case Study from a Climate Vulnerable Country. Int. J. Built Environ. Sustain. 2014, 1. [CrossRef] 
24. Parant, A.; Pascual, A.; Jugel, M.; Kerroume, M.; Felonneau, M.L.; Guéguen, N. Raising Students Awareness to Climate Change: An Illustration with Binding Communication. Environ. Behav. 2017, 49, 339-353. [CrossRef]

25. Freije, A.M.; Hussain, T.; Salman, E.A. Global Warming Awareness among the University of Bahrain Science Students. J. Assoc. Arab Univ. Basic Appl. Sci. 2017, 22, 9-16. [CrossRef]

26. Ayanlade, A.; Jegede, M.O. Climate Change Education and Knowledge among Nigerian University Graduates. Weather Clim. Soc. 2016, 8, 465-473. [CrossRef]

27. Buggy, C.J.; McGlynn, G. Title Climate Change Awareness in a Developing Nations' Second Level Education System-Tanzania. In Proceedings of the 2nd Annual International Conference on Sustainable Development, New York, NY, USA, 23-24 September 2014; United Nations Sustainable Development Network: New York, NY, USA, 2014.

28. Aphunu, A.; Nwabeze, G.O. Fish Farmers' Perception of Climate Change Impact on Fish Production in Delta State, Nigeria. J. Agric. Ext. 2012, 16,1-13. [CrossRef]

29. Elum, Z.A.; Modise, D.M.; Marr, A. Farmer's Perception of Climate Change and Responsive Strategies in Three Selected Provinces of South Africa. Clim. Risk Manag. 2017, 16, 246-257. [CrossRef]

30. UNFCC. Summary for Policymakers 2015 Climate Action Now; United Nations Climate Change Secretariat: Bonn, Germany, 2015; Available online: https:/ / unfccc.int/resource/docs/publications/impacts.pdf (accessed on 25 October 2018).

31. UNDP. Goal 13: Climate Action / UNDP. Available online: http:/ / www.undp.org/content/sdfinance/en/ home/sdg/goal-13--climate-action.html (accessed on 20 December 2018).

32. European Commission. Climate Action and Sustainable Development in Horizon 2020. 2014. Available online: http:/ / eurofed.stis.belspo.be/Downloads /Factsheet\%20on\%20Climate\%20Action\%20and\%20Sustainable\% 20Development\%20in\%20H2020.pdf (accessed on 7 December 2018).

33. Werft, M. Global Goal 13: Taking Climate Action. Available online: https://www.globalcitizen.org/en/ content/global-goal-13-climate-action/ (accessed on 26 October 2018).

34. Masud, M.M.; Akhtar, R.; Afroz, R.; Al-Amin, A.Q.; Kari, F.B. Pro-Environmental Behavior and Public Understanding of Climate Change. Mitig. Adapt. Strateg. Glob. Chang. 2015, 20, 591-600. [CrossRef]

35. Bradley, J.C.; Waliczek, T.M.; Zajicek, J.M. Relationship between Environmental Knowledge and Environmental Attitude of High School Students. J. Environ. Educ. 1999, 30, 17-21. [CrossRef]

36. Ajzen, I. The Theory of Planned Behavior. Organ. Behav. Hum. Decis. Process. 1991, 50, 179-211. [CrossRef]

37. Greenhalgh, T. Assessing a Combined Theories Approach to Climate Change Communication Repository Citation; University of Nevada: Las Vegas, NV, USA, 2011; Available online: https:/ /digitalscholarship.unlv.edu/cgi/ viewcontent.cgi? article $=2244 \&$ context=thesesdissertations (accessed on 3 June 2018).

38. Slater, M.D. Integrating Application of Media Effects, Persuasion, and Behavior Change Theories to Communication Campaigns: A Stages-of-Change Framework. Health Commun. 1999, 11, 335-354. [CrossRef]

39. Fishbein, M.; Yzer, M.C. Using Theory to Design Effective Health Behavior Interventions. Commun. Theory 2003, 13, 164-183. [CrossRef]

40. Shahadu, H. Youth Understanding of Climate: Towards a Theory of Social Adaptation to Climate Change in Africa. Master's Dissertation, London School of Economics and Political Science, London, UK, 2012.

41. Bandura, A. Self-Efficacy Mechanism in Human Agency. Am. Psychol. 1982, 37, 122. [CrossRef]

42. Bandura, A. Social Cognitive: An Agentic Perspective. Annu. Rev. Psychol. 2001, 52, 1-26. [CrossRef]

43. Babbie, E.R. Types of Study Design. In Survey Research Methods, 2nd ed.; Cengage Learning: Boston, MA, USA, 1990; ISBN 13 978-0534126728.

44. Smith, S. Determining Sample Size: How to Ensure You Get the Correct Sample Size. E-Book (c) Qualtrics Online Sample. 2013. Available online: https://www.qualtrics.com/experiencemanagement/research/ determine-sample-size/ (accessed on 29 November 2018).

45. Israel, G.D. Determining Sample Size; University of Florida Cooperative Extension Service, Institute of Food and Agriculture Sciences, EDIS: Gainesville, FL, USA, 1992.

46. Whitmarsh, L. Survey Questionnaire (Climate Change Version 1). 2003. Available online: http://doc. ukdataservice.ac.uk/doc/5345/mrdoc/pdf/5345userguide.pdf (accessed on 12 December 2018).

47. ENVSEC. Questionnaire on Adaptation to Climate Change and Potential Measures. Environment and Security Initiative; n.d. Available online: http:/ / documents.rec.org/events/albania_nov20/Questionnaire\% 20on\%20CCA\%20and\%20measures\%20in\%20Albania.pdf (accessed on 12 December 2018).

48. Salant, P.; Dillman, D.A. How to Conduct Your Own Survey; Cengage Learning: Boston, MA, USA, 1996; ISBN 13 978-0534126728. 
49. Aziz, N.; Zain, Z.; Mafuzi, R.M.Z.R.; Mustapa, A.M.; Najib, N.H.M.; Lah, N.F.N. Relative Importance Index (RII) in Ranking of Procrastination Factors among University Students. AIP Conf. Proc. 2016, 1761, 020022. [CrossRef]

50. Somiah, M.K.; Osei-Poku, G.; Aidoo, I. Relative Importance Analysis of Factors Influencing Unauthorized Siting of Residential Buildings in the Sekondi-Takoradi Metropolis of Ghana. J. Build. Constr. Plan. Res. 2015, 3, 117-126. [CrossRef]

51. Badu, E.; Owusu-Manu, D.G.; Edwards, D.J.; Adesi, M.; Lichtenstein, S. Rural Infrastructure Development in the Volta Region of Ghana: Barriers and Interventions. J. Financ. Manag. Prop. Constr. 2013, 18, 142-159. [CrossRef]

52. Nwankwoala, H.N.L. Causes of Climate and Environmental Changes: The Need for Environmental-Friendly Education Policy in Nigeria. J. Educ. Pract. 2015, 6, 224-234.

53. Gerber, P.; Steinfeld, H.; Henderson, B.; Mottet, A.; Opio, C.; Dijkman, J.; Falucci, A.; Tempio, G. Tackling Climate Change through Livestock-A Global Assessment of Emissions and Mitigation Opportunities; Food and Agriculture Organization of the United Nations (FAO): Rome, Italy, 2013.

54. Henders, S.; Persson, U.M.; Kastner, T. Trading Forests: Land-Use Change and Carbon Emissions Embodied in Production and Exports of Forest-Risk Commodities. Environ. Res. Lett. 2015, 10, 125012. [CrossRef]

55. Haupt, F.; Streck, C.; Bakhtary, H.; Galt, H. Taking a Bite out of Climate Change: Why We Should Stop Harming the Planet and Ourselves by Eating Too Much Beef. Working Paper Prepared by Climate Focus. 2017. Available online: https:/ / climatefocus.com/sites/default/ files/Spreads\%20cf-clua-beef-201710252-spreads.pdf (accessed on 26 September 2018).

56. Singh, P.; Sharma, V.P. Integrated Plastic Waste Management: Environmental and Improved Health Approaches. Procedia Environ. Sci. 2016, 35, 692-700. [CrossRef]

57. Bord, R.J.; O'Connor, R.E.; Fisher, A. In What Sense Does the Public Need to Understand Global Climate Change? Public Underst. Sci. 2000, 9, 205-218. [CrossRef]

58. Islam, S.N.; Winkel, J. Climate Change and Social Inequality; DESA Working Paper No. 152 ST/ESA/2017/ DWP/152; UNDESA: New York, NY, USA, 2017; Available online: http:/ /www.un.org/esa/desa/papers / 2017/wp152_2017.pdf (accessed on 30 November 2018).

59. Otzelberger, A. Tackling the Double Injustice of Climate Change and Gender Inequality Tackling the Double Injustice of Climate Change and Gender Inequality; CARE, Climate Change and Gender Division: Londres, UK, 2014; Available online: https://www.carefrance.org/ressources/themas/1/4442,CARE_COP20_Tackling-doubleinjustic.pdf (accessed on 5 December 2018).

60. Scheffran, J.; Brzoska, M.; Kominek, J.; Link, P.M.; Schilling, J. Climate Change and Violent Conflict. Science 2012, 336, 869-871. [CrossRef]

61. Hsiang, S.M.; Burke, M.; Miguel, E. Quantifying the Influence of Climate on Human Conflict. Science 2013, 341, 1235367. [CrossRef]

62. Messer, E. Climate Change and Violent Conflict: A Critical Literature Review. Oxfam America: Research Backgrounders. 2010. Available online: https://www.oxfamamerica.org/static/media/files/climatechange-and-violent-conflict.pdf (accessed on 30 October 2018).

63. Olsen, L. The Employment Effects of Climate Change and Climate Change Responses: A Role for InternaTional Labour Standards? GURN. 2009. Available online: http:/ /www.ilo.org/wcmsp5/groups/public/--ed_dialogue/---actrav/documents/publication/wcms_122181.pdf (accessed on 13 December 2018).

64. OFXAM. A Climate in Crisis. A Climate in Crisis: How Climate Change Is Making Drought and Humanitarian Disaster Worse in East Africa. Oxfam Media Briefing. 2017. Available online: https://www.oxfam.org/sites/ www.oxfam.org/files/file_attachments/mb-climate-crisis-east-africa-drought-270417-en.pdf (accessed on 20 December 2018).

65. Lezzaik, K.; Milewski, A. A Quantitative Assessment of Groundwater Resources in the Middle East and North Africa Region. Hydrogeol. J. 2018, 251-266. [CrossRef]

66. Holbrook, A.L.; Krosnick, J.A.; Pfent, A. The Causes and Consequences of Response Rates in Surveys by the News Media and Government Contractor Survey Research Firms. In Advances in Telephone Survey Methodology; John Wiley \& Sons, Inc.: Hoboken, NJ, USA, 2007; pp. 499-528.

(c) 2019 by the authors. Licensee MDPI, Basel, Switzerland. This article is an open access article distributed under the terms and conditions of the Creative Commons Attribution (CC BY) license (http:/ / creativecommons.org/licenses/by/4.0/). 